\title{
THE IMPORTANCE OF PRODUCTIVITY OF PROCESSES IN OVERCOMING THE EFFECTS OF THE ECONOMIC CRISIS
}

DATA PRZESŁANIA: 23.09.2017| DATA AKCEPTACJI: 12.11.2017| KODY JEL: 040, 047, 032

\author{
Dariusz Milewski \\ Wydział Zarządzania i Ekonomiki Usług, Uniwersytet Szczeciński \\ dariusz.milewski@wzieu.pl
}

\section{Bogusz Wiśnicki}

Wydział Inżynieryjno-Ekonomiczny Transportu, Akademia Morska w Szczecinie b.wisnicki@am.szczecin.pl

\section{Basilis Masoulas}

Changeland.com

b.masoulas@changeland.com

\begin{abstract}
SUMMARY $\quad$ The objective of the paper is to present the role productivity and thus: (a) diminish the impact of the global financial crisis and (b) provide the means for growth not only for companies but also for a whole economy. Special emphasis was placed on methods of increasing productivity - Lean Manufacturing and Six Sigma methodology. The authors studied research literature and case studies of companies which have implemented Lean - Six Sigma methodology, and proved that (a) the implementations of Lean - Six Sigma methodology have improved process efficiency, and (b) such process efficiency improvements helped the companies overcome the effects of the financial crisis. The studied companies originate from different industrial sectors and from different countries in the world. As complement to the research results found in the literature and also as a comparison authors made also research concerning Poland and Greece.

KEYWORDS Lean Manufacturing, Six Sigma, productivity of processes, economical efficiency, global financial crisis, economical growth
\end{abstract}

\section{THE BACKGROUND AND THE GOAL OF THE PAPER}

The global financial crisis which unexpectedly broke out in 2008 and in fact still last today, affected enormously the global economy and our life, and have also political consequences. It was big surprise and forced to redefine to date economical and political views. Also traditional theory of economy has been questioned. 
According to Adamczyk (2012), the causes of the modern financial crisis was the result of (a) Bill Clinton administration's decision to grant mortgage loans to people with lower incomes and (b) the American Federal Reserve Bank's (FED's) decision to reduce interest rates from $6.5 \%$ in 2001 to $1 \%$ in 2003. Low interest rates in combination with low inflation resulted in the economic growth of 7.5\% in Q3 2003 (Gradziuk, Koczor, 2008, p. 1). The economies of both the developed and developing countries experienced economic downturn due to falling demand and shocks in the financial markets and currency.

In 2009 the world GDP fell by $2.9 \%$. In 2010 the situation was improved - the world's GDP was $3.8 \%$, but in 2011 fell again to $2.4 \%$. The main cause of this GDP's decline was the collapse of the world trade (Adamczyk, 2012).

According to Taylor (2010, p. 53-59) the biggest mistake during crisis was the wrong assessment of the sources of the crisis made by central banks, which wrongly assumed that the cause of the recession was the lack of financial liquidity. On the other hand some authors state, that the problem was not wrong means, but that central banks reacted late (Rosati, 2010, p. 109-110).

It is believed, that all economies (highly developed and emerging markets) felt the results of the crisis because of two reasons: (i) the decline in the demand and (ii) the collapse of the financial and currency markets (Czekaj, 2010, s. 196). These were mainly due to the instability of the market environment which resulted in raising the risk of overproduction.

According to data collected in the EFIGE project (2012) there are big differences between EU countries as far as the level of the productivity of companies is concerned. It appears that the most productive companies prior to the crisis showed greater resistance to the effects of the global slowdown. In turn the high level of productivity was conditioned by the investments in knowledge assets and the implementation of a rigid framework of rules. The size of such investment in itself though does not necessarily have any impact on the indicators of productivity and faster economic growth.

The conclusion drawn from the EFIGE project can be, that the improvement in the efficiency of processes of enterprises is not the only condition for the economic growth. Support in other areas is also required. Nevertheless, process efficiency improvement is an important factor of the success of companies and the economy as a whole.

Although however the character and roots of the crisis were financial, its effects were felt in the real economy. So, the question is: if the improvements in the economy can reverse the negative trend and help in recovering from the crisis? Of course, governments play an important role in steering proper economy policies. But what is the importance of the so called "traditional" factors of the economic growth such as increase in productivity, cost reduction and processes efficiency improvements at the level of individual companies?

The idea of the paper and research conducted by its authors was to find an answer to the above question. In this analysis the special attention was paid to one of the methods of improving the productivity of processes, namely - the operational methods Lean - Management combined with Six Sigma. The intention of the authors was to study if these methods can improve significantly operational efficiency and if this improvement result in the economic growth even in today's crisis environment.

Information and data has been collected from different sources - scientific papers and research studies. The authors used also case studies of enterprises (also from the scientific literature), which 
introduced the concept of Lean Management. Some of the cases have been analyzed with the help of the consulting company Changeland.com, which implements Lean Six - Sigma in enterprises. As the authors of the paper come from Poland and Greece, some part of the research concern implementation of this methodology also in our countries.

\section{GLOBAL SUPPLY CHAINS AND THEIR ENVIRONMENT}

A critical factor in the success of a modern enterprise is the responsiveness to changing circumstances in an unstable environment. Reaction time in business can be reduced through better cooperation in networks, by identifying the needs of customers, exchanging of information between partners in chains and supply chains and improving logistics processes and production (Christopher, 2005). Of course, the need for such an approach, not only in the field of logistics itself has been being postulated in the literature for years. It is worth, however, to ask whether this problem is not particularly important in times of crisis.

According to M. Christopher and M. Holweg ability for such rapid response should be a fundamental feature of logistics systems and supply chains in the modern world (Christopher, Holweg, 2011). Environment for businesses will be characterized by the increasingly instability and unpredictability. The global financial crisis, that began in 2008, probably won't be the last. Beyond this uncertainty also results from other phenomena such as terrorism, natural disasters, war, changes in the prices of raw materials and so on. Therefore, in different publications the authors propose the use of the concept of the so-called "Agile supply chains" (Helo, Xiao, Roger, 2006; Kisperska-Moron, Swierczek, 2009), which can be defined as "the ability of an organization to effectively reconfigure operations and processes, business relationships in an ever changing environment" (Martin, 2000; Kidd, 2000). Its effective implementation allows for the rapid introduction of new, customized, high-quality products and delivering them in accordance with the requirements of customers (Dekkers, Luttervelt, 2006). M. Christopher proposes to move from the "dynamic" flexibility of the supply chains to the structural one. Such a approach requires of course efficient management of processes.

\section{THE CONCEPT OF LEAN MANAGEMENT AND SIX SIGMA}

Lean Manufacturing is a philosophy of production enterprise management that concentrates on identification and elimination of waste from a value stream in order to decrease lead time between a customer's order of a specific product and delivery of the finished product to a recipient (Bożek, Hamrol, 2012). The aim of Lean is defined as to create simplified, efficient value-adding processes while sharing information. The effects of implementation of Lean are lower inventory cost, higher productivity and flexibility, and faster response time to the customer (Subramaniam, 2007).

Lean Management is currently one of the best known and most widely used in the practice of business management concepts. Alternatively, this concept is called Lean Manufacturing or Lean Production, in short - the concept of Lean.

In the 80 s and 90 s the competitive advantage, which the system gives, was recognized by individual US companies (e.g. Ford) and American scientists (incl. R.J. Schonberger, J.P. Womack and 
D.T. Jones, J. Liker), who then spread it to the world (see. R.J. Schonberger, 1982; R.J. Schonberger 1986; J.P. Womack, D.T. Jones, D. Roos, 2008; J.P. Womack, D.T. Jones, 2008; Liker J. (ed.), 1998; J. Liker, 2005; J. Liker, M. Hoseus 2009).

Six Sigma uses methods and statistical analysis tools in order to eliminate defects. The aim boosting financial results by systematic improvements of processes and reduction of their variability (Harry, Schroeder, 2001; Hamrol, 2007). Companies which have adopted Six Sigma have reported increase financial performance in short term (Thomas, Barton et al. 2009), cost reduction (Anchanga, 2006), improvement in customer satisfaction and cost saving (Sharma, 2003). On the other hand, not all the companies that implement a Continuous Improvement programed have been able to capture its entire economic benefits (Cusumano, 1994; Bossert, 2003; Sharma, 2003).

"Lean Six Sigma" (LSS) in turn is the Six Sigma methodology coupled with Lean manufacturing tools. Lean Six Sigma is a methodology and toolset that enables analyzung processes and achieve breakthrough improvement.

Many organizations implement Six Sigma, including most Fortune 500 companies (Nakhai, Neves, 2009). Operational and economical effectiveness of the both concepts (Lean and SS) have been the subject of many studies (Yeung et al., 2006; Corbett et al., 2005; Kinney, Wempe, 2002; Swink, Jacobs, 2012; Shafer, Moeller, 2012). The results of the research shows, that generally the methods are really effective (Atmaca, Ediz, Girenes, 2009; Arumugam, 2013; ChiaJouLin, 2013; Dyah Diwasasri Ratnaningtyas, 2013), although the advantages depend upon characteristics of a firm.

Financial benefits after implementation of LSS on global companies can be found in Brue \& Howes (2006). We know many positive examples from countries like USA and Japan, but there many also evidences of effectiveness of LSS from all over the world. For example, the research conducted in Turkish white goods industry revealed positive results of Six Sigma implementation. Performance of interviewed companies improved significantly among others $-80-100 \%$ in costs, productivity and profitability, $60-79 \%$ in competitiveness and $40-59 \%$ in customer satisfaction (Muzaffer et. al., 2016).

Research made in Romania reveals, that depending on a company, its specificity and a scale of operation savings on costs for example can from thousands to billions of dollars per year (see also: Dumetrescu, Dumitrache, 2011).

Also new fields are being investigated - service sector, energy industry. Important factor of economical efficiency of companies and a whole economy are costs energy, which, in turn, are influenced by the prices of the energy and its consumption. Also, in the production of energy rules of LM and SS can be effectively adopted (Schnellbacha, Reinharta, 2015).

The question arises here however - if even tools like Lean have real positive effects on productivity - so how important is this productivity for financial results of companies and how it in turn enables an increase of economic growth?

In order to find an answer to the first question the information, in form of case studies, have been gathered from the consulting company Changeland.com. The results of the research are presented in Table 1, which shows indicative case studies of companies. They are all clients of Changeland.com., who implemented lean management solutions since 2001 in 3 continents and benefited from Lean Six Sigma methodology. 
These companies conduct their businesses in different sectors of economies and what's worth stressing - not only in industry but also in the service sector. It is not easy to find general rule concerning for example the relation between a type of business and effectiveness of the implementations of Lean concept. Besides the effects have different character. In some cases, the result were lower costs in other better efficiency of processes. In some case that was better customer service. So, the positive impact can relate both sides of a process:

- input (costs, expenditures, workload),

- output (incomes).

Three cases (Telecommunications, Electrical appliances, Paper production) give evidence, that Six Sigma implementation can result in the market growth.

Table 1. Effects of introducing six sigma in companies

\begin{tabular}{|c|c|c|c|c|}
\hline $\begin{array}{c}\text { Business } \\
\text { Sector }\end{array}$ & $\begin{array}{c}\text { Problem/goal } \\
\text { of a project }\end{array}$ & Solution & Aim & Results \\
\hline $\begin{array}{l}\text { Information } \\
\text { Technology } \\
\text { and } \\
\text { Telecommuni- } \\
\text { cations }\end{array}$ & $\begin{array}{l}\text { Overload of } \\
\text { information } \\
\text { generated by } \\
\text { client feedback }\end{array}$ & $\begin{array}{l}\text { Develop mechanisms } \\
\text { for effectively } \\
\text { managing customer } \\
\text { generated information } \\
\text { and the company's } \\
\text { experience and } \\
\text { innovation } \\
\end{array}$ & $\begin{array}{l}\text { Translate customer } \\
\text { information into } \\
\text { a source for improving the } \\
\text { company's products and } \\
\text { services }\end{array}$ & $\begin{array}{l}\text { Anticipate customer needs } \\
\text { for future product and } \\
\text { service development. } \\
\text { Respond efficiently and } \\
\text { effectively to problem } \\
\text { reports }\end{array}$ \\
\hline $\begin{array}{l}\text { Cement } \\
\text { production }\end{array}$ & $\begin{array}{l}\text { To facilitate } \\
\text { knowledge } \\
\text { transfer among } \\
\text { company factories } \\
\text { to reduce costs } \\
\text { and provide } \\
\text { a platform for } \\
\text { innovation } \\
\text { and increased } \\
\text { competitiveness }\end{array}$ & $\begin{array}{l}\text { Design \& formation } \\
\text { of multifuctional } \\
\text { and multyfactory } \\
\text { teams called } \\
\text { "Technology Groups". } \\
\text { Implementation of } \\
\text { process regulating the } \\
\text { TG fuctioning }\end{array}$ & $\begin{array}{l}\text { To document and share } \\
\text { useful practices and } \\
\text { solutions to business } \\
\text { problems appearing in each } \\
\text { factory (use as a template } \\
\text { the Six Sigma DMAIC } \\
\text { method). }\end{array}$ & $\begin{array}{l}\text { In the } 8 \text { months following } \\
\text { project termination, the } \\
\text { Technology Group's } \\
\text { accomplished large } \\
\text { reduction of costs } \\
\text { stemming from "mistake } \\
\text { repetition" and "wheel } \\
\text { reinvention" }\end{array}$ \\
\hline $\begin{array}{l}\text { Financial } \\
\text { Services }\end{array}$ & $\begin{array}{l}\text { The Mortgage } \\
\text { Services division } \\
\text { of a bank was } \\
\text { confronting } \\
\text { a high \& } \\
\text { increasing rate of } \\
\text { bad debt }\end{array}$ & $\begin{array}{l}\text { Implement } \\
\text { Six Sigma BB } \\
\text { improvement project } \\
\text { on debt sales and } \\
\text { collection processes } \\
\text { simultaneously in } \\
\text { different regions }\end{array}$ & $\begin{array}{l}\text { (i) Improve processes } \\
\text { orienting them towards } \\
\text { customer satisfaction; } \\
\text { (ii) increasing personnel } \\
\text { participation and (iii) } \\
\text { identifying and satisfying } \\
\text { needs on skill development } \\
\text { and information } \\
\text { management }\end{array}$ & $\begin{array}{l}\text { Increasing rates of debt } \\
\text { payment }\end{array}$ \\
\hline $\begin{array}{l}\text { Home } \\
\text { appliances }\end{array}$ & $\begin{array}{l}\text { Intellectual capital } \\
\text { leakage due to the } \\
\text { shift of employees } \\
\text { that participate } \\
\text { in the FMP } \\
\text { project to other } \\
\text { companies due to } \\
\text { job dissatisfaction }\end{array}$ & $\begin{array}{l}\text { Factory Master } \\
\text { Plan (FMP) - } \\
\text { implementation of } \\
\text { LEAN's Just-In-Time } \\
\text { and Total-Preventive- } \\
\text { Maintenance concepts }\end{array}$ & $\begin{array}{l}\text { (i) Motivate employees not } \\
\text { to leave the company. } \\
\text { (ii) Reduce damage when } \\
\text { employees leave company }\end{array}$ & $\begin{array}{l}\text { Improved employee } \\
\text { satisfaction. Decreased } \\
\text { employee moving } \\
\text { to other companies. } \\
\text { Reduced significantly } \\
\text { leak of intellectual capital. } \\
\text { Improved training program } \\
\text { re FMP }\end{array}$ \\
\hline
\end{tabular}




\begin{tabular}{|c|c|c|c|c|}
\hline $\begin{array}{c}\text { Business } \\
\text { Sector }\end{array}$ & $\begin{array}{c}\text { Problem/goal } \\
\text { of a project }\end{array}$ & Solution & Aim & Results \\
\hline $\begin{array}{l}\text { Telecommuni- } \\
\text { cations }\end{array}$ & $\begin{array}{l}\text { Losing market } \\
\text { share due } \\
\text { to strong } \\
\text { competition } \\
\text { from various } \\
\text { international } \\
\text { companies based } \\
\text { on the quality } \\
\text { of service rather } \\
\text { than on price } \\
\text { or technological } \\
\text { infrastructure }\end{array}$ & $\begin{array}{l}\text { The consultants were } \\
\text { invited to provide } \\
\text { tools and techniques } \\
\text { that reduce service } \\
\text { defects \& customer } \\
\text { complaints, facilitate } \\
\text { participative decision } \\
\text { making, strategic } \\
\text { planning and } \\
\text { utilization of the } \\
\text { intellectual resources } \\
\text { of the company }\end{array}$ & $\begin{array}{l}\text { (i) Reduce the training } \\
\text { period employees needed } \\
\text { to catch up with the latest } \\
\text { technological developments } \\
\text { in the field, (ii) help } \\
\text { employees quickly transfer } \\
\text { new skills to their jobs } \\
\text { and (iii) to provide a high } \\
\text { standard of service to their } \\
\text { clients, to continue to play } \\
\text { a role in their market }\end{array}$ & $\begin{array}{l}\text { Customer complaints } \\
\text { where reduced significantly, } \\
\text { customer and employee } \\
\text { satisfaction was increased. } \\
\text { Market share was stabilized. } \\
12 \text { months later lost market } \\
\text { share was recovered. }\end{array}$ \\
\hline Brewery & $\begin{array}{l}\text { Conflicts between } \\
\text { employees, } \\
\text { departments and } \\
\text { with customers. } \\
\text { Lack of employee } \\
\text { motivation, lack } \\
\text { of inter-personal } \\
\text { communication as } \\
\text { well as problems } \\
\text { in planning, } \\
\text { organizing and } \\
\text { team integration } \\
\end{array}$ & $\begin{array}{l}\text { LEAN Six Sigma } \\
\text { project to improve } \\
\text { company's soft } \\
\text { processes. } 5 \text { directors } \\
\text { and } 23 \text { employee } \\
\text { representatives } \\
\text { participated in the } \\
\text { Project }\end{array}$ & $\begin{array}{l}\text { (i) Achieve a change of } \\
\text { culture in the Quality } \\
\text { Assurance Department } \\
\text { of the company, towards } \\
\text { a more participative one; } \\
\text { (ii) improve teamwork } \\
\text { and communication; (iii) } \\
\text { improve departmental } \\
\text { processes }\end{array}$ & $\begin{array}{l}\text { Conflicts were eliminated. } \\
\text { Customer and Employee } \\
\text { satisfaction increased } \\
\text { significantly. } \\
12 \text { months later Company } \\
\text { achieved 'Best Place to } \\
\text { Work' award }\end{array}$ \\
\hline $\begin{array}{l}\text { Food } \\
\text { production } \\
\text { and packaging }\end{array}$ & $\begin{array}{l}\text { To implement } \\
\text { and keep live ISO } \\
\text { system in a new } \\
\text { factory }\end{array}$ & $\begin{array}{l}4 \text { LEAN Six Sigma } \\
\text { projects to document } \\
\text { LEAN Value Stream } \\
\text { Map of all business } \\
\text { processes, perform } \\
\text { basic improvements } \\
\text { using } 5 \text { S and other } \\
\text { LEAN concepts }\end{array}$ & $\begin{array}{l}\text { (i) Standardized production } \\
\text { processes; (ii) identification } \\
\text { and development } \\
\text { of organizational } \\
\text { requirements on specialized } \\
\text { skill; (iii) decrease training } \\
\text { life cycle; (iv) reduce 'wheel } \\
\text { re-invention' and 'same } \\
\text { mistake repetition' }\end{array}$ & $\begin{array}{l}\text { New Factory was } \\
\text { successfully implemented } \\
\text { ISO and achieved } \\
\text { certification. } \\
\text { New customized } \\
\text { learning and experience } \\
\text { management processes } \\
\text { where implemented } \\
\text { successfully both in the } \\
\text { new and old factories }\end{array}$ \\
\hline $\begin{array}{l}\text { Hazardous } \\
\text { waste } \\
\text { management }\end{array}$ & $\begin{array}{l}\text { To obtain ISO } \\
\text { certificate in } \\
\text { order to increase } \\
\text { portfolio of clients } \\
\text { and avoid existing } \\
\text { financial problems. }\end{array}$ & $\begin{array}{l}\text { LEAN Six Sigma } \\
\text { project to document } \\
\text { LEAN Value Stream } \\
\text { Map of all laboratory } \\
\text { processes, perform } \\
\text { basic improvements } \\
\text { using } 5 \text { S and other } \\
\text { LEAN concepts. }\end{array}$ & $\begin{array}{l}\text { (i) Improving the lab's } \\
\text { productivity, (ii) obtaining } \\
\text { the certification and (iii) } \\
\text { identifying and satisfying } \\
\text { needs on skill development } \\
\text { and information } \\
\text { management }\end{array}$ & $\begin{array}{l}\text { ISO certification achieved } \\
\text { in half time than } \\
\text { anticipated. Customer } \\
\text { portfolio doubled } \\
\text { in } 6 \text { months }\end{array}$ \\
\hline $\begin{array}{l}\text { Electrical } \\
\text { appliances }\end{array}$ & $\begin{array}{l}\text { The organizational } \\
\text { structure } \\
\text { was highly } \\
\text { hierarchical } \\
\text { and there was } \\
\text { no quality } \\
\text { management } \\
\text { system } \\
\text { implemented }\end{array}$ & ISO certification & $\begin{array}{l}\text { To facilitate the change } \\
\text { (i) towards a participative } \\
\text { culture, } \\
\text { (ii) the standardization of } \\
\text { processes, and (iii) design } \\
\text { of customized training } \\
\text { systems for the employees }\end{array}$ & $\begin{array}{l}8 \text { months after project } \\
\text { completion customized } \\
\text { processes for participative } \\
\text { and collaborative decision } \\
\text { making and working were } \\
\text { fully implemented with } \\
\text { evident results in Customer } \\
\text { retention and portfolio } \\
\text { growth }\end{array}$ \\
\hline
\end{tabular}




\begin{tabular}{|l|l|l|l|l|}
\hline \multicolumn{1}{|c|}{$\begin{array}{c}\text { Business } \\
\text { Sector }\end{array}$} & $\begin{array}{c}\text { Problem/goal } \\
\text { of a project }\end{array}$ & \multicolumn{1}{c|}{ Solution } & \multicolumn{1}{c|}{ Aim } & \multicolumn{1}{c|}{ Results } \\
\hline $\begin{array}{l}\text { Paper } \\
\text { production }\end{array}$ & $\begin{array}{l}\text { Nonstandard } \\
\text { business processes } \\
\text { were not allowing } \\
\text { company } \\
\text { implement } \\
\text { strategic decision } \\
\text { of expanding } \\
\text { globally via } \\
\text { franchising }\end{array}$ & $\begin{array}{l}\text { 5 LEAN Six Sigma } \\
\text { projects to document } \\
\text { LEAN Value Stream } \\
\text { Map of all business } \\
\text { processes, improve } \\
\text { processes \& prepare } \\
\text { franchise pack. }\end{array}$ & $\begin{array}{l}\text { Facilitate the process of } \\
\text { franchising the company } \\
\text { brand and its concept of } \\
\text { a model shop }\end{array}$ & $\begin{array}{l}\text { 2 months after project } \\
\text { completion, first franchise } \\
\text { shop was opened. } \\
12 \text { months after project } \\
\text { completion, } 8 \text { franchise } \\
\text { shop were opened. }\end{array}$ \\
\hline
\end{tabular}

Source: http://consulting.changeland.com/.

Apart from cases from table 1 Changeland Consulting Ltd provided also other information concerning the effectiveness of LSS. In the period from 2004 to 2008, Changeland and the Athens University of Economics and Business (AUEB) developed and implemented a Program for testing the application and impact of Lean Six Sigma in 20 Greek companies, based on the respective survey conducted (Masoulas, 2008).

The results of this survey are as follows:

1. The 20 Greek companies, applying LEAN Six Sigma, were led to more efficient production processes and significantly reduced risks and their exposure to financial and macroeconomic factors.

2. In general, the experience from using LEAN Six Sigma was particularly positive, given its wide acceptance by the companies-clients and their employees.

3. Due to its positive impact on business results, LEAN Six Sigma projects implemented in particular businesses units of large corporations evolved into contracts aimed at deploying LEAN Six Sigma to all the companies in the corporation. This further advocates the acceptance of the method. 4. Workers who used LEAN Six Sigma during business improvement projects, next adopted it in their daily work and/or decided to become LEAN Six Sigma consultants.

5. Comments from people who compared the LEAN Six Sigma tools with TQM (Total Quaility Management) or BPR (Business Process Reangineering) tools revealed that the LEAN Six Sigma tools effectively address the problem of involving stakeholders in the project and are preferred over the other tools.

The results of the responses before and after the implementation of the LEAN Six Sigma projects are following:

1. Innovation: Greater openness to changes. Participants also felt that after the project new ideas were taken more into account than before.

2. Human Resources Development: bigger participation decisions process regarding the way work is performed. supervisors perceived their role as facilitators and mentors; they perceived their job as providing support to colleagues to succeed rather than simply giving instructions to subordinates.

3. Environmental Adaptability: organizations responded to environmental changes with more flexibility and in a less forced manner.

4. Cooperation: different departments or executives of the organization involved in the LEAN Six Sigma project acted in a more cooperative manner, showed mutual support and worked as a team much more than before the project. 
5. Commitment: a significant increase was observed in the commitment to organizational goals.

6. Joint Improvement: after the completion of the LEAN Six Sigma projects the participants felt that people and technology are almost as important for the organization.

The study seems to confirm the theses included in the scientific and professional literature. Many results have relatively more qualitative than quantitative and economical character, but undoubtedly effects like greater cooperation between different departments and bigger commitment of workers lay foundations for the increase of future productivity, better financial results and the economic growth.

\section{THE IMPORTANCE OF PRODUCTIVITY FOR THE ECONOMICAL EFFECTIVENESS OF ENTERPRISES AND ECONOMIC GROWTH. THE CASE OF POLAND}

Over the last 25 years, the Polish economy has doubled its size, measured by real GDP. It is the 8 EU economy in terms of real GDP (McKinsey). Poland was successful among others thanks to growing exports, strong domestic demand, improving productivity, foreign direct investment, EU funds and favorable demographic trends. Today these drivers of growth slow down - the value of foreign investment and productivity growth is decreasing.

So the question is if it possible to return to the growth path through increased productivity of the whole economy?

No doubt there are reserves of productivity in Poland. Productivity in Poland is one-third lower than in the EU-15. The biggest challenges: mining (77\% difference in productivity in relation to the EU-15), agriculture (59\%) And energy (48\%).

The global economic crisis came as a surprise for Polish companies. In 2008, 84 out of 10 surveyed companies reported a decline in turnover while forecasts pointed to an increase of $12 \%$ to 16\% (Przybylski, 2009a). Interestingly, most companies turned to the conservative strategy for the financing and development (Kostecka, 2011). 83\% of companies surveyed considered good relationships with business partners as crucial to their business. More than $46 \%$ believe that long-term contracts are a positive element of the business cooperation, stabilizing economic activity and allowing for long planning. The results of these studies indicate a growing awareness of the business benefits of integration (Eurologistics, 2011).

The results of the KPMG (KPMG, 2009) study of the Polish market confirmed that the global economic crisis has made companies now attach far more attention to the aspects of the cost of their operations, less engaging in activities aimed at the development. The scale of the challenges the Polish managers are currently facing, are well illustrated by the results of international surveys conducted by KPMG. Most Polish companies are aware of the consequences of the economic slowdown and has already started or intend to take actions to reduce costs. Within the framework of savings initiatives, the vast majority of Polish companies (75\%) take actions related to the optimization of business processes.

In the period 2006-2009 KPMG conducted two series of studies: of approx. 700 companies operating on different continents and on a group of over 70 Polish companies in late January and early February 2009. Results of both studies revealed a similar trend - acting under conditions of high uncertainty, most companies (usually more than $90 \%$ of respondents) recognize the need to 
implement measures to optimize the cost structure, which will allow to maintain profitability in a situation of falling revenues.

A very positive phenomenon is the fact that in times of economic slowdown, Polish companies are not limited to the search for savings but intend to continue to actively increase revenue. Despite the economic slowdown, Polish companies believe in its competitiveness and want to actively look for markets to sell their goods and services. Only less than 5\% of those surveyed said they focus exclusively on savings initiatives without taking action aimed at increasing revenue.

Although supply chain integration may seem like a burden in times of crisis, when companies are forced to reduce purchases, it is the integration in the chain and cooperation with operators offering more high-quality services than low costs that proved to be a better solution than the use of cheaper services companies. Shippers and logistics operators working closely together in partnership, are able to adapt to changed circumstances (like the customers) and to propose innovative solutions, that help their customers reduce costs (Przybylski, 2009). In this context also the results of the research conducted by Capgemini are interesting. According to them the crisis caused the company focus on short-term anti-crisis measures, attach less importance to the market requirements and greater emphasis is placed on cost savings (Gąsowska, 2011).

The conclusions that arise from above cited studies and publications are, that productivity of processes still play important role in contemporary circumstances of enterprises. What's more just during global crisis this productivity can be one of the most important factor of recovering from the crisis.

\section{IMPLEMENTATION OF LEAN MANAGEMENT AND SIX SIGMA IN POLAND}

The most frequently mentioned goal of implementing Lean / Kaizen in a company of the surveyed enterprise in Poland (Piasecka-Głuszak, 2013) was the optimization of production and administrative processes $(14.77 \%)$, continuous improvement (12.5\%), increasing the efficiency, productivity, financial profit $(10.23 \%)$, elimination of waste $(10.23 \%)$, minimizing costs $(9.09 \%)$, employee involvement in process improvement, creation of proposals for improvement $(9.09 \%)$. The primary motivations for implementing such concepts in the Polish companies are saving (economical, personnel, materials), increase of productivity, efficiency, labor productivity, employee involvement in process improvement.

The results of surveys conducted in Polish companies confirm that implementing the principles of Lean Management like constant elimination of all waste and all non-value adding activities can bring many benefits. The analyzed companies were different in terms of number of employees, industry, organizational structure, but then homogeneous in several aspects, such as the desire to maximizing its profits, reducing costs, maintaining competitive edge. In the context of the problem analyzed in this paper it is interesting that some companies declared, that the biggest benefits of implementing Lean concept, had been felt by them during the financial crisis.

There are even stated views that a company, which doesn't use the Lean Management and Six Sigma is under high risk of failure. So it is interesting if such views are not exaggerated and if the scale of benefits depend on a branch (sector of economy), in which companies operate. Such a question is justified, because Lean Management (Lean Manufacturing) originate from the au- 
tomotive industry and the basic model of Lean is a copy of production system of Toyota. What's more positive examples of effective implementation of Lean can be found just in the automotive companies like Porsche or Nissan. So the question if Lean Management can useful also in other industrial branches and also in the service sector is justified.

In order to find an answer to the above stated first question P. Walentynowicz conducted in years 2008-2011 the research in 10 big and middle-sized manufacturing companies (Walentynowicz, 2015). The obtained results confirm the analyses made the researchers. Depending on a branch the introduced methods, scope of Lean solutions and also results of their implementations are different. Generally, it is confirmed, that the biggest benefits are in the production systems using machines and assembly processes. Lean is relatively less useful in the extractive and apparatus industries. Yet the philosophy of LM characterized by e.g. reducing wastes can be useful in any kind of activity and can have positive impact on financial situation of a company.

Also the results of other studies seem to confirm these thesis. For example, in 2015 there were researches conducted in 48 Polish enterprises from other types of activities and of different sized (micro, middle sized, and big one's enterprises from manufacturing, services, construction industry, and agriculture) (Krasiński, 2015). The studied companies maintained, that Lean helped them in recovering from their (internal) crisis. Some of the companies use the concept to prevent happening the crisis in a future. It is necessary also to notice, that most of the companies use the tool of Lean-Six Sigma in the selective way. It can be concluded, that Lean doesn't have to be implemented as whole, like for example in Toyota. But more important conclusion, which arises here, is that it can be introduced gradually, starting from selected tools. It is of course important for smaller organizations, for which the implementation of the Lean system can be costly.

Another interesting publication concerns also the comparison of effectiveness of Lean and Six Sigma. Bożek and Hamrol (Bożek, Hamrol, 2012) analysed the case study Polish company specializing in manufacturing medical items in which both had been implemented. The major benefits of LM implementation consists in shortening and stabilizing lead time and as result - reduction of inventories. There are no proofs however that LM contributes to $20-30 \%$ boost in productivity. The cause are: wide product assortment, fluctuating demand for particular groups of products and a programme of acquiring new production items from another locations of the corporation. According to authors opinion if $25 \%$ of waste can be transformed into value added activitites, one gets $10 \%$ increase of labour activity, what can translate into saving 100 employees and consequently PLN 3,6 M a year.

In this company also Six Sigma was implemented. 15 projects we completed in the last 12 months - projected annual savings were estimated - the aggregate amount of the planned savings has reached 1,7 M PLN (2012). According to estimations savings will amount to 20 millions PLN in the next 5 years. Projected productivity growth will reach $15-20 \%$ a year and amount to $80 \%$ after 5 years.

The LSS can yet effective also in the service sector what has been proved by some researchers. Studies conducted by them concerned for example medical (Urban, 2016) and banking sectors. The case of Poland confirm wider trend - Lean is becoming popular in the medical service also in other countries, for example in Great Britain (Burgess, Radnor, 2013). 


\section{CONCLUSIONS}

Based on the analyzed data from surveys and case studies it can be concluded that the productivity of the processes is an important factor for productivity of a company and for an ability of recovering from a financial crisis. So the first hypothesis seems to be confirmed, provided, however, that the improvement in productivity should result not just only cost savings, but also sales improvement. To improve the productivity the concept of Lean Management in conjunction Six Sigma may be helpful, but again under condition, that the effectiveness of Lean is varied and is best suited for companies executing complex business processes, and, above all, in the sphere of industrial production.

The biggest problem concern the relation between productivity and the economic growth especially on the macroeconomic level. Although it may seem obvious and logical that improvement in economic results of companies affects the economic growth of a whole economy it is difficult to find evidences for such some relations. There is lack of research studies concerning this problem. It is difficult even to find statistical data reflecting such a correlation.

That's why on this stage of the research we can't say for sure what is more important from the point of view of the economic growth - economic policy, independent from enterprises external factors or their internal engagement in process improvements, innovations, good strategies.

That's why authors postulate to continue research on this problem.

\section{LITERATURE}

Adamczyk, M. (2012). Współczesny kryzys finansowy - przyczyny i konsekwencje dla gospodarki światowej. Prace i Materiały Instytutu Handlu Zagranicznego Uniwersytetu Gdańskiego, 31, 13-29.

Anchanga, P. (2006). Critical success factor for lean implementation within SMEs. Journal of Manufacturing Technology Management, 17 (4), 11.

Atmaca, E., Girenes, S.S. (2009). Literatür Araştırması: Altı Sigma Metodolojisi. Süleyman Demirel Üniversitesi İIBF Dergisi, Gazi, 3 (14), 111-126.

Bossert, J. (2003). Lean and Six Sigma-synergy made in heaven. Quality Progress, 36 (7), 31.

Bożek, M., Hamrol, A. (2012). Analysis of efficiency of Lean Manufacturing and Six Sigma in a production enterprise. Management and Production Engineering Review, 3 (4), 14-25.

Brue, G., Howes, R. (2006). Six Sigma. New York: McGraw-Hill.

Burgess, N., Radnor Z. (2013). Evaluating lean in healthcare. International Journal of Health Care Quality Assurance, 26 (3), 220-235.

Chia J.L., Frank Ch.F., Hung-da W., Yuh M. Ch., Kuriger G. (2013). Continuous improvement of knowledge management systems using Six Sigma methodology. Robotics and Computer-Integrated Manufacturing, 29 (3), 95-103.

Christopher, M., Holweg, M. (2011). "Supply Chain 2.0": managing supply chains in the era of turbulence. International Journal of Physical Distribution \& Logistics Management, 41 (1), 63-82.

Christopher, M. (2005). Creating Value - Adding Networks. Harlow: Prentice Hall.

Corbett, C.J., Montes-Sancho, M.J., Kirsch, D.A. (2005). The financial impact of ISO 9000 certification in the United States: an empirical analysis. Management Science, 51 (7), 1046-1059.

Cusumano, M. (1994). The Limits of “Lean". Sloan Management Review, 35 (4), 5, 27-32.

Czekaj, J. (2010). Wpływ Światowego kryzysu gospodarczego na polską gospodarkę. In: G. Kołodko (ed.), Globalizacja, kryzys i co dalej s. 189-209. Warszawa: Poltext Sp. z o.o.

Dekkers, R., van Luttervelt, C.A. (2006). Industrial networks: capturing changeability? International Journal of Networks and Virtual Organisations, 3 (1), 1-24.

Dumetrescu, C., Dumitrache, M. (2011). The Impact of Lean Six Sigma on the Overall Results of Companies. Economia. Management, 14 (2), 535-544. 
European Firms In a Global Economy: Internal policies for external competitiveness (EFIGE) (EU-FP 7) (2008-2012).

Global Employment Trends 2013: Recovering from a second jobs dip. Report (2013). Geneva: International Labour Office, June 9.

Gradziuk, A., Koczor, M. (2008). Unia Europejska a kryzys na amerykańskim rynku finansowym. In: S. Dębski, A. Kondek, Ł. Kulesa (ed.), Biuletyn Polskiego Instytutu Spraw Międzynarodowych, 45.

Harry, M., Schroeder, R. (2001). Six Sigma. Using quality enhancement to improve financial results [in Polish: Six Sigma. Wykorzystanie poprawy jakości do poprawy wyników finansowych]. Kraków: Oficyna Ekonomiczna.

Hamrol, A. (2010). Zarządzanie jakościq z przykładami, Quality management with examples. Warszawa: Wydawnictwo Naukowe PWN.

Helo, P., Xiao, Y., Jiao, Roger, J. (2006). A web-based logistics management system for agile supply demand network design. Journal of Manufacturing Technology Management, 17 (8), 1058-1077.

Kidd, P.T. (2000). Agile manufacturing: a strategy for the 21st century. Retrieved form: www.cheshirehenbury.com/agility/ agilitypapers/paper1095.html (13.09.2017).

Kinney, M.R., Wempe, W.F. (2002). Further evidence on the extent and origins of JIT's profitability effects. The Accounting Review, 77 (1), 203-225.

Kisperska-Moron, D., Swierczek, A. (2009). The agile capabilities of Polish companies in the supply chain: An empirical study. International Journal of Production Economics, 18, 217-224.

Kostecka, A. (2011). Kooperacja nakręca rozwój. Eurologistics, 2.

Krasiński, M. (2015). Lean management w zapobieganiu i przezwyciężaniu kryzysu w przedsiębiorstwie. Marketing i Rynek, 5.

Martin, C. (2000). The agile supply chain: competing in volatile markets. Industrial Marketing Management, 1 (29), 37-44.

Masoulas, B. (2008). Managing Growth with Lean Six Sigma. Kleidarythmos.

Muzaffer, E., Muhemmetali, T. (MAİMAİTİAİLİTUERDİ), AIHEMAITUOHETI WUJIABUDULA (2016). The Effects of Six Sigma Approach on Business Perfomance: A Study of White Goods (home appliances) Sector in Turkey. Procedia Social and Behavioral Sciences, 229, 444-452.

Nakhai, B., Neves, J.S. (2009). The challenges of Six Sigma in improving service quality. International Journal of Quality \& Reliability Management, 25 (7), 663-684.

Piasecka-Głuszak, A. (2013). Korzyści z wdrożenia lean management w polskich przedsiębiorstwach w dobie kryzysu wyniki badań ankietowych. Prace Naukowe Uniwersytetu Ekonomicznego we Wrocławiu, 315, 99-111.

Przybylski, R. (2009a). Współpraca na niepewne czasy. Rzeczpospolita, 19 czerwca. Retrieved from: www.rp.pl/artykul/321909-Wspolpraca-na-niepewne-czasy.html (17.09.2017).

Przybylski, R. (2009b). Logistyka po nowemu. Rzeczpospolita, dodatek: Logistyka - Transport -Spedycja.

Ratnaningtyas, D.D., Surendro, K. (2013). Information Quality Improvement Model on Hospital Information System Using Six Sigma. Procedia Technology, 9, 1166-1172.

Redukcja kosztów - doraźna potrzeba czy długofalowe działanie? Jak polskie przedsiębiorstwa podchodza do optymalizacji kosztów, raport KPMG w Polsce 2009. Retrieved from: www.kpmg.pl (23.04.2009).

Revkin, A.C. (2008). Are Oil Costs Creating a 'Made Here' Movement? New York Times August 2.

Rohter, L. (2008). Shipping Costs Start to Crimp Globalization. New York Times, August 3.

Rosati, D. (2010). Przyczyny i mechanizmy kryzysu finansowego w USA w latach 2007-2009. W: G. Kołodko (red.), Globalizacja, kryzys i co dalej? (p. 315-351). Warszawa: Poltext Sp. z o.o.

Schnellbach, P., Reinhart, G. (2015). Evaluating the Effects of Energy Productivity Measures on Lean Production Key Performance Indicators. Procedia CIRP, 26, 492-497.

Shafer, S.M., Moeller, S.B. (2012). The effects of Six Sigma on corporate performance: an empirical investigation. Journal of Operations Management, 30 (7-8), 521-532.

Sharma, U. (2003). Implementing Lean principles with the Six Sigma advantage: How a batterycompany realized significant improvements. Journal of Organizational Excellence, 22 (3), 43-52.

Subramaniam, A. (2007). Integrating Lean Six Sigma, Projects to your strategy - How to integrate LSS - People, Systems, Methods, Roadmaps, Tools \& Techniques. Retrieved from: www.slideshare.net/anandsubramaniam/lean-six-sigma-projects-strategy-linkage (13.09.2017).

Swink, M., Jacobs, B.W. (2012). Six Sigma adoption: operating performance impacts and contextual drivers of success. Journal of Operations Management, 30 (6), 437-453.

Szanse i zagrożenia $w$ rozwoju dużych firm $w$ Polsce 2010 (2011). Eurologistics. 2, 31-32.

Szreter, P. (2011). Kierunek stabilizacja. Eurologistics, 2, 74. 
Taylor, J.B. (2010). Zrozumieć kryzys finansowy. Warszawa: Wydawnictwo Naukowe PWN. Retrieved from: http://www.wto. org/english/news_e/pres12_e/pr658_e.htm\#table1 (15.03.2012).

Thomas, A.J., Web, D. (2003). Quality systems implementation in Welsh small to medium-sized entrerprises: a global comparison and a model for change. Journal of Engineering Manufacture, 217 (4), 6.

Thomas, A., Barton, R., Chuke-Okafor, C. (2009). Applying lean six sigma in a small engineering company - a model for change. Journal of Manufacturing Technology Management, 20 (1), 113-129.

Tomlin, B. (2006). On the value of mitigation and contingency for managing supply chain disruption risks. Management Science, 52 (5), 639-657.

Walentynowicz, P. (2015). Zakres zastosowania lean management w przedsiębiorstwach produkcyjnych - wyniki badań empirycznych. Przedsiębiorczość i Zarządzanie, XVI (3), 69-80.

Urban, W. (2016). Usługowa specyfika strumienia wartości. Prace Naukowe Uniwersytetu Ekonomicznego we Wrocławiu, 421, 591-602.

Wing, Y.H., Nouri J.S., Nilay S. (2006). Object-oriented dynamic supply chain modeling incorporated with production scheduling. European Journal of Operational Research, 169, 1064-1076.

Yeung, A.C.L., Cheng, T.C.E., Lai, K. (2006). An operational and institutional perspective on total quality management. Production and Operations Management, 15 (1), 156-170.

\section{ZNACZENIE PRODUKTYWNOŚCI PROCESÓW W PRZEZWYCIĘŻANIU SKUTKÓW KRYZYSU GOSPODARCZEGO}

\begin{tabular}{l|l} 
STRESZCZENIE & Celem artykułu jest przedstawienie roli produktywności, która jest związana z zmniejszeniem
\end{tabular} wpływu światowego kryzysu finansowego i zapewnieniem środków do wzrostu nie tylko dla firm, ale także dla całej gospodarki. Szczególny nacisk położono na metody zwiększania produktywności - metodologię Lean Manufacturing i Six Sigma. Autorzy przeanalizowali literaturę badawczą i studia przypadków firm, które wdrożyły metodologię Lean - Six Sigma, i udowodnili, że wdrożenia metodologii Lean - Six Sigma poprawiły efektywność procesu oraz że taka poprawa wydajności procesu pomogła firmom pokonać skutki kryzysu finansowego. Badane firmy pochodzą z różnych sektorów przemysłu i z różnych krajów świata. Uzupełnienie wyniki badań w literaturze oraz własnych, dokonano również badań dotyczących Polski i Grecji.

SŁOWA KLUCZOWE Lean Manufacturing, Six Sigma, wydajność procesów, efektywność ekonomiczna, globalny kryzys finansowy, wzrost gospodarczy

Translated by Dariusz Milewski 
